\title{
Unlike nectar foragers, honeybee drones (Apis mellifera) are not able to utilize starch as fuel for flight ${ }^{1}$
}

\author{
Norbert HRASSNIGG*, Robert BRODSCHNEIDER, Paul H. FleISCHMANN, \\ Karl CRAILSHEIM \\ Institute for Zoology, Karl-Franzens-Universität Graz, Universitätsplatz 2, A-8010 Graz, Austria
}

Received 8 April 2004 - revised 11 February 2005 - accepted 21 February 2005

Published online 19 October 2005

\begin{abstract}
Nectar foragers collected at a feeding station and fed $10 \mu \mathrm{L}$ of a 2 molar glucose solution, increased their period of flight in a roundabout by $30.2 \%$ when they were fed additional soluble starch (10 $\mu \mathrm{L}, 2 \mathrm{M}$ glucose $+1 \mathrm{M}$ glucose equivalents as amylose). The increase in flight period and flight distance was about the same as for workers fed a pure 3 molar glucose, or another glucose plus starch solution $(2.5 \mathrm{M}$ glucose $+0.5 \mathrm{M}$ glucose equivalents). In drones, feeding additional starch did not alter the flight period or the distance flown, either in normal or dwarf drones. Feeding honey plus starch did not alter the flight period, although the honey contained some starch-degrading amylase. The longer oligosaccharides in syrup produced by starch hydrolyses are said to have a negative impact on overwintering bees. However, from our results we infer that nectar foragers are well equipped with enzymes to efficiently degrade amylose to glucose, which underlines the workers' central role as food processors within the honeybee colony.
\end{abstract}

Apis mellifera / digestion / amylose / amylase / flight metabolism / enzyme

\section{INTRODUCTION}

Insects utilise various high-energy fuels for flight. They derive energy to meet the intense metabolic needs of flight from carbohydrates, fat or amino acids such as proline (Wheeler, 1989; Candy, 1989). During flight, honeybees increase their metabolic rate to relatively high values (Nachtigall et al., 1989; Rothe and Nachtigall, 1989; Hrassnigg and Crailsheim, 1999; Harrison and Fewell, 2002; Feuerbacher et al., 2003; Stabentheiner et al., 2003). Since honeybee drones and workers do not store relevant amounts of energy reserves in their body - only minor quantities of glycogen (Panzenböck and Crailsheim, 1997), and fat are found (c.f. Gilbert, 1967; reviewed by Hrassnigg and Crailsheim, 2005) - they rely almost solely on

\footnotetext{
* Corresponding author: norbert.hrassnigg@uni-graz.at
}

${ }^{1}$ Manuscript editor: Klaus Hartfelder the energy stored in their honey stomach, primarily in a solution of various sugars (honey). Since the power output of flight muscles is high during flight, these muscles must be provided with fuel at higher levels than under resting conditions. Therefore, during flight the transport of sugar molecules from the honey stomach to the flight muscles has to be a quick process. To fuel the flight, enzymatic degradation of carbohydrate polymers also has to be relatively quick.

The main constituents of the honeybees' food are nectar or honey, the primary carbohydrate source, and pollen, which contains not only proteins but also carbohydrates such as starch. To be absorbed into the hemolymph, large molecules like proteins or polysaccharides have to be degraded to smaller monomers 
(Turunen and Crailsheim, 1996). This is done by various enzymes in the course of the digestion process. The amount of digestive enzymes a bee produces varies with gender, age and occupation (Halberstadt, 1980; Moritz and Crailsheim, 1987; Gilliam et al., 1988; Takenaka et al., 1990; Szolderits and Crailsheim, 1993; Kubo et al., 1996; Costa and Cruz-Landim, 2001, 2002). At younger ages, workers ingest much pollen as nurses and produce more proteolytic enzymes in their midgut, to degrade the pollen proteins (Moritz and Crailsheim, 1987; Crailsheim et al., 1992). Older workers (foragers) have much lower levels of proteolytic enzymes in the midgut, but produce elevated amounts of carbohydrate-digesting enzymes in their hypopharyngeal glands, such as $\alpha$-glucosidase, also referred to as saccharase or invertase (Maurizio, 1962b; Simpson et al., 1968; Delage-Darchen et al., 1982; Kubo et al., 1996), glucose oxidase and amylase (Takenaka et al., 1990; Ohashi et al., 1999). These enzymes are also found in honey stored in the combs (White, 1957). In addition to the hypopharyngeal gland, other salivary glands also produce carbohydrases (Arnold and Delage-Darchen, 1978; Costa and CruzLandim, 2001) as does the midgut (Maurizio, 1957, 1962a; Delage-Darchen et al., 1982). Lotmar (1935) found that workers kept in cages for several days were able to digest starch given to them in a solution with sucrose. By feeding a specific volume of an $8 \%$ sucrose $+8 \%$ starch solution, she increased their life-span compared to workers supplied with the same volume of a pure $8 \%$ sucrose solution.

In contrast to workers, drones do not have hypopharyngeal glands (Snodgrass, 1956). Furthermore, it is not known if drones are able to produce amylase in their midgut and therefore whether they can digest starch at all. But, as drones are not involved in collecting or processing food (Mindt, 1962), the absence of enzymes such as amylase should not pose a problem. Their primary and, as far as known, only task is to produce sperm and to mate with queens. To meet this demand, they are quick and forceful flyers (Koeniger, 1988; Gmeinbauer and Crailsheim, 1993; Coelho, 1996). For flight they derive energy from starch-free honey, which they ingest from the honey cells in the colony (Free, 1957).
It has not previously been determined whether drones are able to digest starch, nor whether they can utilise it for flight. It has been established that workers are able to digest starch, but not whether the process is quick enough to sustain flight metabolism. To investigate this, we stimulated nectar foragers and drones to fly in a roundabout after they had been fed glucose and glucose-starch solutions. Before the flights, some drones were fed with diluted honey and some with diluted honey mixed with starch, to analyse the effect of the amylases present in honey. If starch is utilised in flight metabolism of bees, an additional supply of this carbohydrate should increase their flight performance (greater flight time and/or a higher number of rounds flown in a roundabout).

\section{MATERIALS AND METHODS}

Nectar foragers and drones were prepared to fly in a roundabout by affixing a small tube on the thorax. Each bee was attached by its tube to the $14 \mathrm{~cm}-$ long arm of a flight mill. Flight was stimulated by removing a small ball of paper that the bees held (see also Hrassnigg and Crailsheim, 1999). The temperature in the roundabout was kept between $25^{\circ} \mathrm{C}$ and $30{ }^{\circ} \mathrm{C}$. The roundabout was surrounded by a piece of stripped cardboard to provide the bees with a homogenous visual environment. In the experiments, soluble starch (amylose according to Zulkowsky from Merck) was always fed in a mixture with sugar or honey to improve its ingestion (Vogel, 1931). Because of its polysaccharide nature, the amount of starch cannot be given in moles directly, therefore the amount was calculated to provide the desired quantities of the monomer anhydroglucose $\left(\mathrm{C}_{6} \mathrm{H}_{10} \mathrm{O}_{5}\right)$ with a molecular weight of $162 \mathrm{~g}$. We increased the amount of starch by $10 \%$ to compensate for the water bound to it physically. To compare the effects of the fed substrates, the concentrations of glucose, starch, and honey are all given as glucose equivalents.

The workers we sampled were collected in September and October as nectar foragers from a feeding station that had been established about $50 \mathrm{~m}$ from the colony and was stocked with a dilute sugar solution ( 1 M sucrose). Drones were collected from three different colonies. Two colonies were provided with normal drone brood containing combs from several other colonies and were kept queenless to prevent the eviction of drones. A third colony was kept with an unmated queen laying only haploid eggs, which provided dwarf drones. Drones were either taken from side frames of the hives, where older drones are 
usually found, or were taken from the window of the beehouse towards which many drones flew after the hive had been opened. Since the drone flight experiments were performed late in the season (September-December), when drones were no longer raised, all the drones were mature and usually ready to fly.

First, the foragers or drones were stimulated to fly in the roundabout without additional feeding (an "emptying flight") to deplete their sugar reserves. Several such flights were monitored and lasted for $590.17 \pm 298.55 \mathrm{~s}(\mathrm{n}=12)$ in workers and $1338.30 \pm$ $735.97 \mathrm{~s}(\mathrm{n}=23)$ in drones. After the workers or drones had stopped to actively fly in the apparatus, they were stimulated again for several times until the movements of wings were very weak. Usually we did not stimulate until no wing movements occurred, because such depleted bees often are not able to ingest the offered sugar solution and soon die. By the weak wing movements and the fact that additional stimulation quickly led to an inability to ingest food, in both the drones and workers, we concluded that the bees were depleted of reserves after emptying flights.

After this first flight the bees were fed defined amounts of sugar or sugar-starch solutions and were stimulated to fly again. The number of turns flown by the bees was recorded by computer and the overall flight time was clocked by the experimenter, so that only the active flight period was considered for further calculations.

In all trials, after the emptying flight the nectar foragers and drones were fed with $10 \mu \mathrm{L}$ of a pure glucose solution $(2$ or $3 \mathrm{M})$, and stimulated to another flight after a resting period of at least five and a maximum of eight minutes. When they were exhausted again, they were taken from the arm of the flight mill and fed with a glucose-starch solution: either $2 \mathrm{M}$ glucose and $1 \mathrm{M}$ starch, calculated as anhydroglucose, or $2.5 \mathrm{M}$ glucose and $0.5 \mathrm{M}$ starch, calculated as anhydroglucose. Most workers and drones were subjected to several flights and were fed with different solutions successively. To avoid possible biases caused by the order of feeding, the sequence was varied.

A potential lack of amylase in the gastro-intestinal tract of drones might possibly be compensated by amylase present in honey. In one set of trials, drones were fed before flight with either honey solution or honey solution mixed with amylose. First, a honey stock solution was prepared from freshly harvested blossom honey; its amylase activity was estimated to be very good by the method described by Zander and Maurizio (1984). For the stock solution, the honey was diluted with distilled water to give a solution that equalled about a $4 \mathrm{M}$ glucose solution. From this solution an equivalent was diluted to give a honey solution equalling a $2 \mathrm{M}$ glucose solution (depicted in Fig. 1 as "honey 2 M"). For the flights fuelled with "honey plus starch", a $50 \mu \mathrm{L}$ volume of the honey solution (4 M) was vigorously mixed with a $50 \mu \mathrm{L}$ volume of an amylose solution ( $2 \mathrm{M}$ anhydroglucose), so that the resulting solution had 2 glucose equivalents from honey and 1 equivalent from starch (designated as "honey+starch $2+1 \mathrm{M}$ " in Fig. 1). This was done right before the drones were fed with $10 \mu \mathrm{L}$ of the solution, to avoid an uncontrolled degradation of the amylose by the enzymes present in the honey.

To extend the period of contact of soluble starch and amylase in the drones' gastrointestine, the group of normal drones was subjected on two repeated flights to the same "sugar + starch" feeding regimes. If drones need just some more time to degrade the starch fed to them, then flight time in second flights should be increased. Another means to enhance the time of a possible starch degradation was achieved by using dwarf drones for flight experiments, which fly for a longer period than normal drones with the same amount of sugar. They were fed the same volumes of glucose solution $(10 \mu \mathrm{L}, 2 \mathrm{M})$ and glucose plus starch solution $(10 \mu \mathrm{L}, 2+1 \mathrm{M})$.

After having been fed a solution with starch, the drones often defecated whitish excreta during flight, which accumulated on the cardboard paper surrounding the carousel. To test for the presence of starch, some of these excreta were dissolved with a droplet of water and subjected to an iodine solution. They stained blue, confirming the presence of starch.

Before and after feeding and after flights each bee was weighed on an analytical balance to the nearest $0.1 \mathrm{mg}$. This was done to check if the fed solution was entirely ingested and to determine each bee's empty body weight after depletion of their energy reserves.

\section{Statistics}

The data are given as mean and standard deviation. Calculations were performed with the statistical software package "Statgraphics Plus 5.0". In the flight experiments 28 different normal drones, 7 dwarf drones, and 27 nectar foragers were used. For calculations of the flight data the sample size (n) gives the number of tested individuals. For reasons given above, many of the normal drones, and also a few workers, were subjected to more than one flight at a specific composition and concentration of administered food. If one individual was used more than once at the same feeding regime, these results were averaged for subsequent comparisons between groups. Many of the bees were fed different solutions successively and, therefore, not all data were independent. Since not all data of the different feeding regimes were distributed normally and had the same variance, differences between the various groups were analysed for statistical significance 
(a)

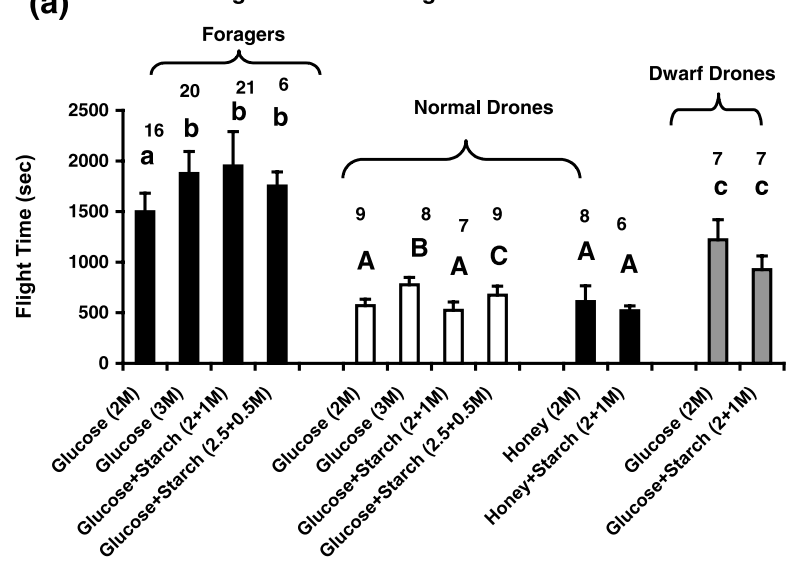

(b)

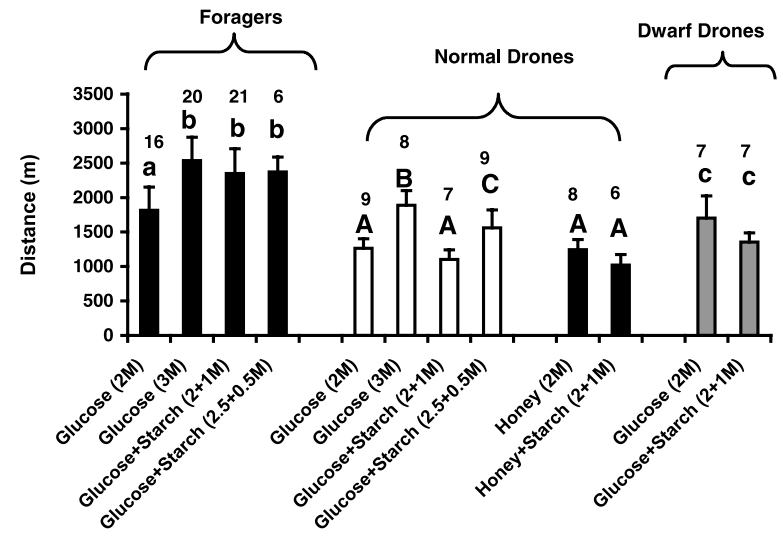

Figure 1. Total flight times (a) and distances flown (b) of nectar foragers, normal and dwarf drones flying in a roundabout after they were fed $10 \mu \mathrm{L}$ of a sugar solution without or with additional starch. The concentration of starch equalled either a $1 \mathrm{M}$ or $0.5 \mathrm{M}$ glucose solution. Shown are means and standard deviations. Identical letters above columns indicate no statistically significant difference within the respective group of foragers, normal drones, and dwarf drones (non parametric ANOVA on ranks; $P<0.05, \mathrm{n}=$ given above columns). using a non-parametric ANOVA (Kruskal-Wallis one way analysis of variance on ranks). Data were checked then by notched box-and-whisker plots, for significant differences. Repeated flights of drones fed with the same "sugar + starch" solution were tested by paired sample comparison (paired signed rank Test). Two sample comparisons were performed with the Mann-Whitney U-test. The level of statistical significance was set at $P<0.05$.

\section{RESULTS}

The mean empty weight of the normal sized drones was $213.57 \pm 15.37 \mathrm{mg}(\mathrm{n}=28)$, of dwarf drones $135.13 \pm 16.94 \mathrm{mg}(\mathrm{n}=7)$, and that of nectar foragers $83.32 \pm 6.95 \mathrm{mg}(\mathrm{n}=27)$. When the same amounts of carbohydrates were fed to normal and dwarf drones and foragers, all the workers flew for significantly longer periods in the roundabout than the drones (see Fig. 1a). The foragers fed with $10 \mu \mathrm{L}$ of a $2 \mathrm{M}$ glucose solution flew significantly shorter periods $($ mean $=1498.44 \pm 183.88 \mathrm{~s}, \mathrm{n}=16)$ compared to foragers fed a $3 \mathrm{M}$ glucose $(1875.10 \pm$ $217.79 \mathrm{~s}, \mathrm{n}=20$ ) or a glucose plus starch solution $(2+1 \mathrm{M}, 1950.52 \pm 339.20 \mathrm{~s}, \mathrm{n}=21 ; 2.5+$ $0.5 \mathrm{M}, 1752.42 \pm 139.29 \mathrm{~s}, \mathrm{n}=6)$. The increase in the flight period of foragers fed additional starch (glucose + starch, $2+1 \mathrm{M}$ ) was $30.2 \%$ compared to foragers fed glucose $(2 \mathrm{M})$ only. Nectar foragers that were fed the glucose solution $(10 \mu \mathrm{L}, 3 \mathrm{M})$ did not differ significantly in flight period from foragers flying with glucose plus starch $(10 \mu \mathrm{L} ; 2+1 \mathrm{M}$ or $2.5+0.5 \mathrm{M})$. This clearly shows that nectar foragers are able to degrade the amylose in the fed solution and to utilise it metabolically in a short period of time. 
Table I. Flight time and distance flown in the roundabout by normal drones subjected to the same feeding regimes on successive flights. In consecutive flights no increase of time or distance flown was detected.

\begin{tabular}{|c|c|c|c|c|c|c|}
\hline $\begin{array}{l}\text { Feeding Regime } \\
\qquad(10 \mu \mathrm{L})\end{array}$ & & 1. Flight & 2. Flight & 3. Flight & $\mathrm{n}$ & $\begin{array}{c}\text { Paired Signed } \\
\text { Rank Test }\end{array}$ \\
\hline \multirow{2}{*}{$\begin{array}{l}\text { Glucose + Starch } \\
\qquad(2+1 \mathrm{M})\end{array}$} & Time (s) & $522.57 \pm 69.50$ & $531.29 \pm 136.80$ & --- & 7 & ns \\
\hline & Distance (m) & $1139.39 \pm 151.53$ & $1073.55 \pm 178.43$ & --- & & $\mathrm{ns}$ \\
\hline \multirow{2}{*}{$\begin{array}{c}\text { Glucose }+ \text { Starch } \\
(2.5+0.5 \mathrm{M})\end{array}$} & Time (s) & $668.22 \pm 109.83$ & $672.56 \pm 90.07$ & --- & 9 & $\mathrm{~ns}$ \\
\hline & Distance (m) & $1491.78 \pm 362.76$ & $1594.99 \pm 256.66$ & --- & & ns \\
\hline \multirow{2}{*}{$\begin{array}{l}\text { Honey + Starch } \\
\quad(2+1 \mathrm{M})\end{array}$} & Time (s) & $517.33 \pm 96.02$ & $493.17 \pm 42.29$ & $550.83 \pm 98.34$ & 6 & $\mathrm{~ns} / \mathrm{ns}$ \\
\hline & Distance $(\mathrm{m})$ & $1031.97 \pm 199.84$ & $984.32 \pm 151.80$ & $1044.14 \pm 196.71$ & & $\mathrm{~ns} / \mathrm{ns}$ \\
\hline
\end{tabular}

Normal drones that were fed $10 \mu \mathrm{L}$ of a $2 \mathrm{M}$ glucose solution flew significantly shorter periods ( $26.7 \%$ shorter) than drones fed a $3 \mathrm{M}$ glucose solution, and significantly shorter $(15.5 \%)$ than those fed a glucose plus starch solution $(2.5+0.5 \mathrm{M})$, which contained more glucose than the pure 2 molar solution (Fig. 1a). Feeding starch did not increase the flight period of drones. This can be seen by comparing their flight periods after they were fed glucose (10 $\mu \mathrm{L}, 2 \mathrm{M})$ versus glucose plus amylose solution $(10 \mu \mathrm{L}, 2+1 \mathrm{M})$; the flight periods were $569.22 \pm 63.50 \mathrm{~s}(\mathrm{n}=9)$ and $523.62 \pm 83.67 \mathrm{~s}$ $(\mathrm{n}=7)$, respectively, with no statistical difference $(P>0.05)$. When the concentration of glucose was increased to $2.5 \mathrm{M}$ and that of amylose was decreased to $0.5 \mathrm{M}$ anhydroglucose units ("glucose plus starch, $2.5+0.5 \mathrm{M}$ "), the flight time was increased by $18.4 \% \quad 673.96 \pm$ $89.48 \mathrm{~s}, \mathrm{n}=9$ ), but did not reach the flight period of drones that were fed the $3 \mathrm{M}$ glucose solution $(776.10 \pm 73.22 \mathrm{~s}, \mathrm{n}=8$; increase $=$ $36.3 \%)$.

When normal drones, fed with sugar and starch, were subjected to a repeated flight, no increase in flight time could be observed (Tab. I). Dwarf drones, fed with glucose solution $(2 \mathrm{M}, 10 \mu \mathrm{L})$, flew significantly longer than normal drones, but shorter than foragers (Fig. 1). Also in these drones additional starch (glucose + starch, $2+1 \mathrm{M}, 10 \mu \mathrm{L}$ ) did not increase the period of flight (Fig. 1).

These results show that, in contrast to nectar foragers, drones are not able to quickly degrade ingested amylose and are not able to utilise it metabolically for flight. They defecated amylose during flight, which was shown by staining their whitish excreta blue with iodine solution.

To investigate the influence of honey amylase on the degradation of starch, we compared the flight times of drones fed with $10 \mu \mathrm{L}$ honey solution ( $2 \mathrm{M}$ glucose equivalents) to those fed honey plus starch $(2+1 \mathrm{M})$. As shown in Figure 1a, there were no statistically significant differences in the flight periods of drones fed honey $(611.00 \pm 155.97 \mathrm{~s}, \mathrm{n}=8)$ and drones fed honey plus starch $(520.44 \pm 48.33 \mathrm{~s}, \mathrm{n}=6$; $P>0.05)$. Even when the drones were fed three times with honey-starch solution in succession, there was neither an increase in the flight period nor in the distance flown (Tab. I).

The mean distance flown in the roundabout by nectar foragers fed with $3 \mathrm{M}$ glucose solution was significantly greater $(2536.00 \pm$ $338.56 \mathrm{~m}, \mathrm{n}=20$ ) than that flown by foragers fed with a $2 \mathrm{M}$ glucose solution (1814.10 \pm $336.09 \mathrm{~m}, \mathrm{n}=16$ ) (Fig. 1b). Also, foragers fed glucose plus starch $(10 \mu \mathrm{L}, 2+1 \mathrm{M}$ or $2.5+$ $0.5 \mathrm{M})$ flew significantly farther: $2350.08 \pm$ $357.27 \mathrm{~m}(\mathrm{n}=21)$ and $2370.57 \pm 217.26 \mathrm{~m}(\mathrm{n}=$ $6)$, respectively $(P<0.05)$. The flight distances of foragers fed with $3 \mathrm{M}$ glucose did not differ significantly from those fed glucose plus starch $(2+1 \mathrm{M}$ and $2.5+0.5 \mathrm{M})$.

When the same amount of carbohydrates was fed to drones and nectar foragers, the distances covered by the drones were significantly shorter (Fig. 1b). Among drones the $3 \mathrm{M}$ glucose group reached the longest distance $(1889.13 \pm$ $211.25 \mathrm{~m})$. The drones fed $2 \mathrm{M}$ glucose 

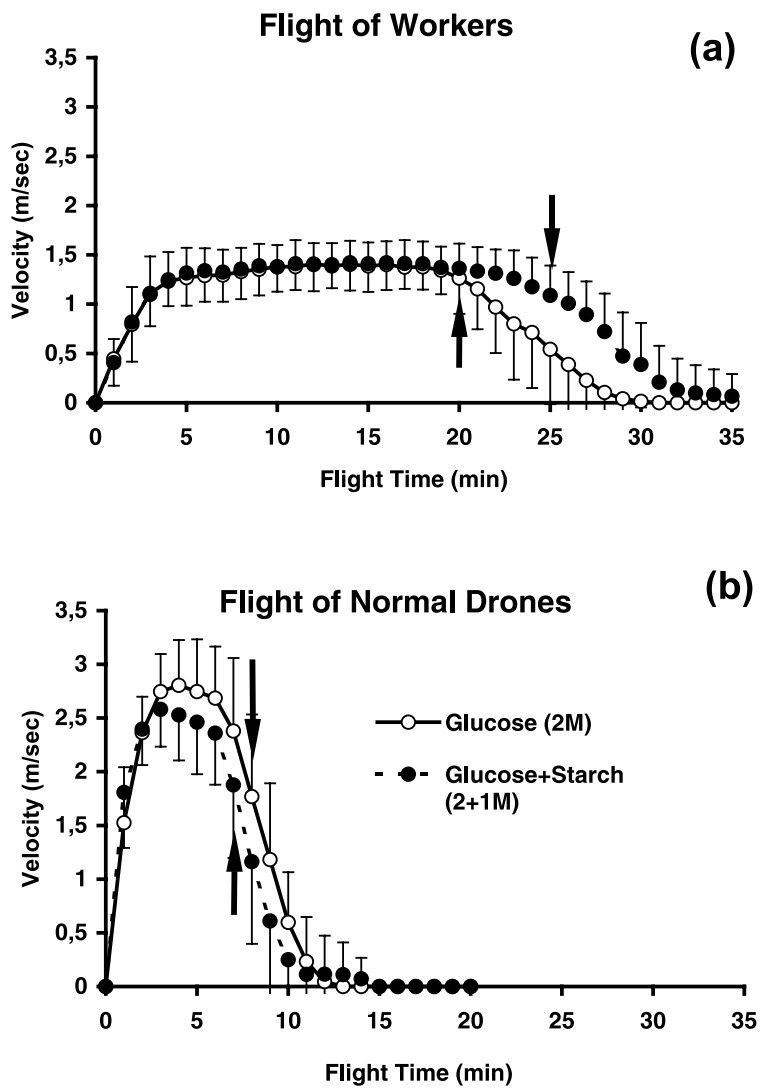

Figure 2. The relation of speed to flight time with nectar foragers (a) and normal sized drones (b) in roundabout flights. The bees were fed either a glucose solution $(10 \mu \mathrm{L}$ at $2 \mathrm{M}$; open symbols) or a glucose-starch solution $(10 \mu \mathrm{L}$, glucose: $\operatorname{starch}=2: 1$, equalling a $3 \mathrm{M}$ glucose solution; closed symbols); means and SD are shown; means were calculated for every point from all individuals, including those which had stopped flying towards the end; left of arrow: all bees were flying, right of arrow: decreasing numbers of bees were flying; flights of drones: each of the 7-9 used individuals performed 2 successive flights, each flight with the same feeding (i.e. 14-18 flights); flights of nectar foragers: 18-22 individuals performed one flight each with the same feeding (1822 flights).
$(1264.54 \pm 137.63 \mathrm{~m})$, those fed glucose plus starch $(2+1 \mathrm{M} ; 1101.42 \pm 140.60 \mathrm{~m})$, those fed honey $(2 \mathrm{M} ; 1244.53 \pm 145.58 \mathrm{~m})$, and those fed honey plus starch $(2+1 \mathrm{M} ; 1020.15 \pm$ $153.33 \mathrm{~m})$ all flew shorter distances, and the flight distances of these four groups were not statistically different from each other. However, the drones fed $2.5 \mathrm{M}$ glucose plus starch (0.5 M anhydroglucose equivalents) did fly significantly farther $(1560.15 \pm 259.19 \mathrm{~m})$. From the flight distance data, as from the period data, we deduce that nectar foragers can quickly utilise the soluble starch, while drones cannot.

The difference between nectar foragers and drones in the ability to utilise starch can also be deduced by comparing the mean velocities of bees that were fed glucose $(2 \mathrm{M})$ or glucose plus starch $(2+1 \mathrm{M})$ (Fig. 2a,b). The mean velocities were calculated from all bees that flew regularly until exhaustion. Until the time indicated by the arrow in the figure, all bees were actively flying, and the mean velocities are representa- tive. After the time indicated by the arrow, individual bees successively stopped flying, and the mean velocity was calculated by including the bees that had stopped. The exhausted bees were included in the calculation to illustrate the different utilization of starch; if only flying bees were included, then a single exceedingly long-flying bee could have masked any difference. The maximum flight speed of drones in the roundabout was by far higher than that of nectar foragers (Fig. 2a,b) - this difference was highly significant (U-Test, $P<0.0001$ ) - but with the same amounts of glucose they were flying for a much shorter period (U-Test, $P<$ 0.0001).

\section{DISCUSSION}

Obviously, roundabout flights with tethered animals do not completely reflect flights as they naturally occur. Bees under free flight 
conditions reach much higher maximal velocities than in a carousel (Oertel, 1956; Koeniger, 1988; Coelho, 1991). Nevertheless, our experimental method is appropriate to answer some metabolic questions, as during such controlled flights the bees invest energy at high and relatively constant rates until exhaustion. The method is especially suitable for investigating the utilization of different nutrients, because energy turnover - and thus turnover of nutrients - very much depends on the kind and intensity of the activity that is performed (Crailsheim et al., 1999; Stabentheiner et al., 2003).

The drones and workers we used for the experiments were not characterised by age, but rather by their function as nectar foragers and flight-drones. It could be criticised that the drones were not as well defined as the foragers, but since the drones were more easily stimulated to fly in the roundabout than the nectar foragers, we consider them having been flight drones, although we did not collect them at the time of mating flights. Our results suggest that foragers are able to degrade starch very quickly, so that they can use the glucose-monomers to fuel their intense flight metabolism. The degradation process was rapid, as the workers were stimulated to fly just 5-8 $\mathrm{min}$ after feeding.

The additional feeding of amylose to drones did not lengthen their flight period in the roundabout. There were no statistically significant differences in flight duration when drones were fed a $2 \mathrm{M}$ glucose solution or a glucose plus starch solution $(2+1 \mathrm{M})$, or a honey plus starch solution $(2+1 \mathrm{M})$ (Fig. 1a). The flights performed with honey and starch show that the content of amylase in the fed honey was not sufficient to degrade the fed amylose in the short time of the flight trial. But also when the drones were fed with honey starch solution for 3 times in succession, and we thereby extended the period of amylose digestion, did not increase the flight time or distance flown (Tab. I). The same can be stated for successive flights with glucose and amylose solution.

With the same amount of glucose, the nectar foragers maintained flight longer than normal and also dwarf drones (2.63 and 1.23 times longer with glucose $2 \mathrm{M}$ ). This is understandable, because the drones were, on average, 2.56 and 1.62 times as heavy as the foragers. Because of the longer flight time, the forager bees presumably had more time to degrade the starch. But this difference was only small in dwarf drones, which showed almost the same flight period as foragers. Within the drones' flight time, we did not even find slightly elevated flight periods or flight distances, neither in normal nor in dwarf drones fed glucose plus starch compared to drones fed glucose only.

In summary, we found no indication that drones utilise amylose quickly in flight. The possibility that drones degrade amylose in the course of longer periods of time cannot be investigated through flight experiments. This is because many of the drones defecated at least part of the fed starch during flight, so that, even if they had enough amylase to degrade the starch, its excretion would prevent a longer lasting digestion process. Another question that cannot be tested by flight experiments is whether younger drones, before they are capable of flight, digest starch more quickly than older drones do.

Since starch is not a main component of honeybee nutrition, and only small amounts are ingested by bees via feeding on pollen, the amount of energy derived from starch is undoubtedly not very high under natural conditions. Only certain kinds of pollen have relatively high starch content - for example, for Zea mays a value of $22.4 \%$ is reported (Stanley and Linskens, 1985). Using the average amounts of honey $(80 \mathrm{~kg})$ and pollen $(20 \mathrm{~kg}) \mathrm{a}$ typical colony consumes per year (Seeley, 1985), we can calculate that the starch in this pollen (app. $10 \%$ of its dry weight) yields an additional amount of $2.0 \mathrm{~kg}$ of anhydroglucose, which is the energy equivalent of about $2.6 \mathrm{~kg}$ of honey, which is only $3.1 \%$ of the total carbohydrates available $(80+2.6 \mathrm{~kg})$. Probably this is an over-estimate, as it assumes that all the starch present is digested and absorbed. Furthermore, it is the younger bees that ingest large quantities of pollen, not the older foraging bees (Crailsheim et al., 1992; Hrassnigg and Crailsheim, 1998), but there is little published information about the ability of young bees to digest starch. Our findings indicate that foragers have the ability to degrade polysaccharides such as starch, but do not indicate the importance of this food source. Amylase does somewhat increase the workers' energetic efficiency, but might be even more important in the general process of pollen digestion. 
Usually, the starch honeybees ingest is encapsulated within pollen in the form of small grains composed of a soluble fraction (amylose) and an insoluble outer layer (amylopectin). Apparently, nectar foragers degraded and utilised very quickly the fed amylose but the degradation of starch, which occurs naturally in the bee diet, seems to be a slower process (Lotmar, 1935). As it is obvious that amylose is easier to digest than whole starch grains, we used quite a high concentration of soluble starch, to investigate the bees' ability to degrade it. In fact, the solution we used was more a milky white suspension than a clear solution, as starch is not easily soluble at concentrations of $8.1 \%$ and $16.2 \%(0.5 \mathrm{M}$ and $1 \mathrm{M}$ anhydroglucose equivalents), which were the concentrations used in the experiments. Nevertheless, the nectar foragers utilised the starch well and flew for as long and as far whether they were fed pure glucose solution $(3 \mathrm{M})$ or glucose plus starch $(2+1 \mathrm{M} ; 2.5+0.5 \mathrm{M})$, while the drones did not show any increase in flight performance.

Under natural conditions, before flights, drones provide themselves with honey from cells (Free, 1957). The honey contains enzymes produced by the workers. In the present experiment, where the drones were fed pure sugar or sugar-starch solution, this was not the case. When presenting preliminary results we supposed that it might be possible that under natural conditions ingested starch could be utilised by the drones via the enzymes provided with honey or the workers' food (Hrassnigg et al., 2003). When we mixed honey with starch in the present investigation, the flight performance was not increased by the addition of honey. This suggests that nectar foragers can very quickly digest starch by enzymatic processes in their digestive tract, and that the amount of amylase found in the honey is rather a byproduct of the workers' ability to digest amylose. From the indications of quick utilization of starch in our experiments, we can deduce that nectar foragers (older workers) produce high amounts of amylase, so that enzyme concentrations in their digestive system are likely much higher than in honey. Therefore they digest the polysaccharide amylase more efficiently than drones.

Our results also indicate that flight-age drones - these have never been observed foraging in the field - are especially adapted to the pre-processed food they take up from honey cells, so that they have no need to produce amylase to be able to digest polysaccharides like starch. This is consistent with the findings that drones ingest very small amounts of pollen, which also corresponds to the reduced presence of proteolytic enzymes in their intestines (Szolderits and Crailsheim, 1993). Also, it is not known whether queens - the reproductive females - are able to utilise starch.

The workers' ability to digest polysaccharides is not only of theoretical interest, but also has applications for practical beekeeping in the context of feeding syrup to honeybee colonies to overcome scarce times during summer or to replenish the colonies' stores before the winter period. Syrup produced by starch hydrolyses may contain not only glucose and maltose but also longer oligosaccharides, which are considered to have a harmful effect on overwintering bees. They are believed to cause dysentery because they introduce indigestible waste materials, resulting in overstrained workers' recta (Phillips, 1927). Our results do not support this belief, at least for nectar foragers. Rather, our data suggest that the degradation of polysaccharide molecules is a quick process in nectar foragers. However, feeding large quantities of syrup solution to a colony all at once could present more of a problem for younger bees, which may be unable to process it quickly enough. To answer questions about the effectiveness of syrup feeding, more detailed investigations will have to be performed with worker bees of different ages at different times of the year and at varying temperatures.

Our results suggest that, to meet their intense metabolic needs for flight, the enzymatic equipment of nectar foragers enables them to quickly utilise, not only sugars, but also amylose. But this ability does not apply to flightdrones. These findings provide additional evidence of the highly evolved division of labour in honeybee colonies. Workers not only forage for food, but also pre-digest carbohydrates for other members of the colony, an activity already described for protein (Crailsheim, 1991, 1992).

\section{ACKNOWLEDGEMENTS}

We are grateful to Richard Nowogrodzki for the critical reading and for improving the English of the manuscript. 
Résumé - Les mâles d'abeilles domestiques (Apis mellifera) ne sont pas capables, contrairement aux butineuses de nectar, d'utiliser l'amidon comme carburant pour le vol. Des butineuses de nectar, prélevées lors de leur arrivée sur la source de nourriture, et des mâles d'abeilles (Apis mellifera L.), définis par leur âge et leur comportement, ont reçu en nourrissement diverses solutions de glucose et de glucose additionné d'amidon, puis ont été placés dans un carrousel de vol (Hrassnigg et Crailsheim, 1999). Après leur capture les insectes ont d'abord été soumis à un premier «vol de nettoyage » i.e. sans nourrissement, au cours duquel ils devaient utiliser toutes leurs réserves alimentaires. On leur a fourni ensuite une solution nutritive donnée et, après une période de repos de 6 à $8 \mathrm{~min}$, ils ont été incités à accomplir un autre vol. Pour une même quantité de nourriture, les mâles ont volé moins longtemps et moins loin que les ouvrières, mais leur vitesse de vol était plus élevée (Fig. 2a, b). Les butineuses ont augmenté leur temps de vol de $30,2 \%$ lorsqu'elles ont reçu une solution de glucose et d'amidon $(10 \mu \mathrm{L}$, glucose $2 \mathrm{M}+$ l'équivalent de glucose $1 \mathrm{M}$ sous forme d'amylose) à la place d'une solution simple de glucose $(10 \mu \mathrm{L}, 2 \mathrm{M})$. L'augmentation du temps et de la distance de vol a été à peu près semblable avec une solution de glucose $3 \mathrm{M}$ ou une autre solution de glucose et d'amidon (glucose 2,5 M et l'équivalent de glucose 0,5 M) comme nourrissement. Ni la durée, ni la distance de vol n'ont été augmentées par l'addition d'amidon au sirop de nourrissement, que ce soit chez les mâles de poids normal $(213,57 \pm 15,37 \mathrm{mg}, \mathrm{n}=28)$ ou chez les mâles nains $(135,13 \pm 16,94 \mathrm{mg}, \mathrm{n}=7$ ) (Fig. 1). Il en a été de même avec une solution de miel et d'amidon, qui correspondait en énergie à une solution de glucose et d'amidon $(2+1 \mathrm{M})$ et contenait l' amylase du miel, qui dégrade l'amidon. Le temps de vol n'a pas été non plus augmenté lorsque les vols ont été répétés avec les mêmes mâles suite à un nourrissement d'amidon (Tab. I), bien que dans ce cas l'amidon ait pu séjourner plus longtemps dans le tube digestif et ait pu être digéré sur une période plus longue. La capacité des ouvrières à digérer les polysaccharides est une donnée importante pour la pratique apicole en liaison avec le nourrissement au sirop. Pour les abeilles qui hivernent les oligosacharides produits par l'hydrolyse de l'amidon doivent avoir une action négative. Il découle de nos résultats qu' au moins les butineuses de nectar possèdent les enzymes pour dégrader efficacement l'amidon soluble en glucose. Le fait que les mâles ne soient pas capables, contrairement aux ouvrières, de dégrader rapidement l'amylose, souligne le rôle central des ouvrières comme élaboreuses de nourriture au sein de la colonie.

Apis mellifera / digestion / amylose / amylase / métabolisme du vol / enzyme

Zusammenfassung - Drohnen (Apis mellifera) sind, im Gegensatz zu Nektarsammlerinnen, nicht in der Lage Stärke als Treibstoff für den Flug zu verwerten. Nektarsammlerinnen, die bei der Ankunft an einem Futterplatz gefangen wurden, und Flugdrohnen, die durch ihr Alter und Verhalten definiert waren, wurden nach der Fütterung verschiedener Glukoselösungen und Glukose plus Stärkelösungen in einem Flugkarussell zum Fliegen stimuliert (Hrassnigg und Crailsheim, 1999). Nach dem Fangen wurden die Tiere zunächst einem ersten Leerflug unterzogen, bei dem sie alle mitgebrachten Futterreserven verbrauchen sollten. Danach wurde ihnen eine definierte Futterlösung verabreicht und nach einer Rastperiode von 5 bis 8 Minuten wurden sie zu einem weiteren Flug angeregt. Drohnen flogen bei gleicher Futtermenge im Karussell zwar weniger lange und weniger weit als Arbeiterinnen, aber sie flogen mit einer höheren Geschwindigkeit als Arbeiterinnen (Abb. 2a, b). Die Nektarsammlerinnen steigerten ihre Flugzeit um 30,2 \%, wenn anstelle einer Glukoselösung $(2 \mathrm{M}, 10 \mu \mathrm{L})$ eine GlukoseStärkelösung ( $10 \mu \mathrm{L}, 2 \mathrm{M}$ Glukose + 1 M Glukoseäquivalente als Amylose) verfüttert wurde (Abb. 1). Die Steigerung der Flugzeit und der Flugdistanz war ungefähr gleich groß wie bei der Fütterung von 3 molarer Glukoselösung oder einer anderen GlukoseStärkelösung $(2.5 \mathrm{M}$ Glukose $+0.5 \mathrm{M}$ Glukose Äquivalent). Weder bei normalen Drohnen, mit einem Gewicht von 213,57 $\pm 15,37 \mathrm{mg}(\mathrm{n}=28)$, noch bei Zwergdrohnen, die $135,13 \pm 16,94 \mathrm{mg}(\mathrm{n}=7)$ schwer waren und dadurch mit der gleichen Futtermenge länger flogen, wurde durch Zufütterung von Stärke eine Steigerung der Flugzeit oder Flugdistanz erreicht (Abb. 1). Auch bei der Fütterung einer Honig-Stärkelösung, welche im Energiegehalt der Glukose-Stärkelösung $(2+1 \mathrm{M})$ entsprach und welche Stärke abbauende Honigamylase enthielt, war die Flugzeit und zurückgelegte Entfernung bei Drohnen nicht verlängert. Eine Steigerung der Flugzeit trat auch dann nicht ein, wenn Flüge mit Stärkefütterung mit derselben Drohne wiederholt wurden (Tab. I), obwohl die Stärke hierbei länger im Verdauungstrakt verweilen konnte und dadurch über einen längeren Zeitraum verdaut werden konnte. Die Fähigkeit von Arbeiterinnen Polysaccharide zu verdauen ist für die praktische Bienenzucht im Zusammenhang mit der Fütterung von Sirup bedeutend. Für überwinternde Bienen sollen die bei der Stärkehydrolyse entstehenden Oligosaccharide eine negative Wirkung haben. Von unseren Ergebnissen leiten wir jedoch $a b$, dass zumindest Nektarsammlerinnen sehr gut mit Enzymen ausgestattet sind, um lösliche Stärke effizient zu Glukose abzubauen. Dass Drohnen im Gegensatz zu Arbeiterinnen nicht in der Lage sind Amylose rasch abzubauen, unterstreicht die zentrale Rolle der Arbeiterinnen als Futterverarbeiterinnen im Bienenvolk.

Verdauung / Amylose / Amylase / Flugmetabolismus / Enzym 


\section{REFERENCES}

Arnold G., Delage-Darchen B. (1978) Nouvelles données sur l'équipement enzymatique des glandes salivaires de l'ouvrière d'Apis mellifica (Hyménoptère Apidés), Ann. Sci. Nat. Zool. 20, 401-422.

Candy D.J. (1989) Utilization of fuels by the flight muscles, in: Goldsworthy G.J., Wheeler C.H. (Eds.), Insect flight, CRC Press, Boca Raton, Florida, pp. 305-319.

Coelho J.R. (1991) Heat transfer and body temperature in honey bee (Hymenoptera: Apidae) drones and workers, Environ. Entomol. 20, 1627 1635.

Coelho J.R. (1996) The flight characteristics of drones in relation to mating, Bee Sci. 4, 21-25.

Costa R.A.C., Cruz-Landim C. (2001) Enzymes present in the thoracic gland extracts from workers and males of Apis mellifera (Hymenoptera: Apidae), Sociobiology 37, 563569.

Costa R.A.C., Cruz-Landim C. (2002) Enzymatic activity of hypopharyngeal gland extracts from workers of Apis mellifera (Hymenoptera, Apidae, Apinae), Sociobiology 40, 403-411.

Crailsheim K. (1991) Interadult feeding of jelly in honeybee (Apis mellifera L.) colonies, J. Comp. Physiol. B 161, 55-60.

Crailsheim K. (1992) The flow of jelly within a honeybee colony, J. Comp. Physiol. B 162, 681689.

Crailsheim K., Schneider L.H.W., Hrassnigg N., Bühlmann G., Brosch U., Gmeinbauer R., Schöffmann B. (1992) Pollen consumption and utilization in worker honeybees (Apis mellifera carnica): Dependence on individual age and function, J. Insect Physiol. 38, 409-419.

Crailsheim K., Stabentheiner A., Hrassnigg N., Leonhard B. (1999) Oxygen consumption at different activity levels and ambient temperatures in isolated honeybees (Hymenoptera: Apidae), Entomol. Gen. 24, 1-12.

Delage-Darchen B., Conconi J.R. de, Aguilar I.C. (1982) The enzymatic equipments of the various salivary and migut glands of Apis mellifica workers and some African and American worker stingless bees, Apidologie 13, 265-273.

Feuerbacher E., Fewell J.H., Roberts S.P., Smith E.F., Harrison J.F. (2003) Effects of load type (pollen or nectar) and load mass on hovering metabolic rate and mechanical power output in the honey bee Apis mellifera, J. Exp. Biol. 206, 1855-1865.

Free J.B. (1957) The food of adult drone honeybees (Apis mellifera), Br. J. Anim. Behav. 5, 7-11.

Gilbert (1967) Lipid metabolism and function in insects, in: Beament J.W.L., Treherne J.E. Wigglesworth V.B. (Eds.), Advances in insect physiology 4, Academic Press, London, pp. 69211.

Gilliam M., Lorenz B.J., Richardson G.V. (1988) Digestive enzymes and micro-organisms in honey bees, Apis mellifera: influence of streptomycin, age, season and pollen, Microbios 55, 95-114.

Gmeinbauer R., Crailsheim K. (1993) Glucose utilization during flight of honeybee (Apis mellifera) workers, drones and queens, J. Insect Physiol. 39, 959-967.

Halberstadt K. (1980) Elektrophoretische Untersuchungen zur Sekretionstätigkeit der Hypopharynxdrüse der Honigbiene (Apis mellifera L.), Insectes Soc. 27, 61-77.

Harrison J.F., Fewell J.H. (2002) Environmental and genetic influences on flight metabolic rate in the honey bee, Apis mellifera, Comp. Biochem. Physiol. A 133, 323-333.

Hrassnigg N., Crailsheim K. (1998) The influence of brood on the pollen consumption of worker bees (Apis mellifera L.), J. Insect Physiol. 44, 393404.

Hrassnigg N., Crailsheim K. (1999) Metabolic rates and metabolic power of honeybees in tethered flight related to temperature and drag (Hymenoptera: Apidae), Entomol. Gen. 24, 2330.

Hrassnigg N., Crailsheim K. (2005) Differences in drone and worker physiology in honeybees (Apis mellifera L.), Apidologie 36, 255-277.

Hrassnigg N., Brodschneider R., Fleischmann P., Crailsheim K. (2003) Worker bees (Apis mellifera L.) are able to utilize starch as fuel for flight while drones are not; 38th Beekeeping Congr., Apimondia 24-29 August, 2003, in Ljubljana, Slovenia.

Koeniger G. (1988) Mating flights of honey bee drones (Apis mellifera L.), Biona Report 6, 2934

Kubo T., Sasaki M., Nakamura J., Sasagawa H., Ohashi K., Takeuchi H., Natori S. (1996) Change in the expression of hypopharyngeal-gland proteins of the worker honeybees (Apis mellifera L.) with age and/or role, J. Biochem. 119, 291295.

Lotmar R. (1935) Abbau und Verwertung der Stärke und Dextrin durch die Honigbiene, Arch. Bienenkd. 16, 195-204.

Maurizio A. (1957) Zuckerabbau unter der Einwirkung der invertierenden Fermente in Pharynxdrüsen und Mitteldarm der Honigbiene (Apis mellifica L.). I. Sommerbienen der Krainerund Nigra-Rasse, Insectes Soc. 4, 225-243.

Maurizio A. (1962a) Zuckerabbau unter der Einwirkung der invertierenden Fermente in Pharynxdruesen und Mitteldarm der Honigbiene (Apis mellifica L.) 4. Sommerbienen der italienischen, kaukasischen und griechischen Rasse, Insectes Soc. 9, 39-72.

Maurizio A. (1962b) Zuckerabbau unter der Einwirkung der invertierenden Fermente in Pharynxdrüsen und Mitteldarm der Honigbiene (Apis mellifica L.), Ann. Abeille 5, 215-232. 
Mindt B. (1962) Untersuchungen über das Leben der Drohnen, insbesondere Ernährung und Geschlechtsreife, Z. Bienenforsch. 6, 9-33.

Moritz B., Crailsheim K. (1987) Physiology of protein digestion in the midgut of the honeybee (Apis mellifera L.), J. Insect Physiol. 33, 923931.

Nachtigall W., Rothe U., Feller P., Jungmann R. (1989) Flight of the honey bee. III. Flight metabolic power calculated from gas analysis, thermoregulation and fuel consumption, J. Comp. Physiol. B 158, 729-737.

Oertel E. (1956) Observations on the flight of drone honey bees, Ann. Entomol. Soc. Am. 49, 497500 .

Ohashi K., Natori S., Kubo T. (1999) Expression of amylase and glucose oxidase in the hypopharyngeal gland with an age-dependent role change of the worker honeybee (Apis mellifera L.), Eur. J. Biochem. 265, 127-133.

Panzenböck U., Crailsheim K. (1997) Glycogen in honeybee queens, workers and drones (Apis mellifera carnica Pollm.), J. Insect Physiol. 43, 155-165.

Phillips E.F. (1927) The utilization of carbohydrates by honeybees, J. Agric. Res. 35, 385-428.

Rothe U., Nachtigall W. (1989) Flight of the honey bee. IV. Respiratory quotients and metabolic rates during sitting, walking and flying, J. Comp. Physiol. B 158, 739-749.

Seeley T.D. (1985) Honeybee Ecology, Princeton University Press, Princeton, New Jersey.

Simpson J., Riedel I.B.M., Wilding N. (1968) Invertase in the hypopharyngeal glands of the honeybee, J. Apic. Res. 7, 29-36.
Snodgrass R.E. (1956) Anatomy of the honey bee, Cornell University Press, London.

Stabentheiner A., Vollmann J., Kovac H., Crailsheim K. (2003) Oxygen consumption and body temperature of active and resting honeybees, J. Insect Physiol. 49, 881-889.

Stanley R.G., Linskens H.F. (1985) Pollen, SpringerVerlag, Berlin, Heidelberg, New York.

Szolderits M.J., Crailsheim K. (1993) A comparison of pollen consumption and digestion in honeybee (Apis mellifera carnica) drones and workers, J. Insect Physiol. 39, 877-881.

Takenaka T., Miwa S., Echigo T. (1990) Changes of protein content and enzyme activity in hypopharyngeal glands during lifespan of honeybee workers (Apis mellifera L.), Bull. Fac. Agric. Tamagawa Univ. 30, 1-8.

Turunen S., Crailsheim K. (1996) Lipid and sugar absorption, in: Lehane M.J., Billingsley P.F. (Eds.), Biology of the insect midgut, Chapman and Hall, London, pp. 293-320.

Vogel B. (1931) Über die Beziehung zwischen Süssgeschmack und Nährwert von Zuckern und Zuckeralkoholen bei der Honigbiene, Z. Vgl. Physiol. 14, 273-347.

Wheeler C.H. (1989) Mobilization and transport of fuels to the flight muscles, in: Goldsworthy G.J., Wheeler C.H. (Eds.), Insect flight, CRC Press, Boca Raton, Florida, pp. 273-303.

White J.W. (1957) The composition of honey, Bee World 38, 57-66.

Zander E., Maurizio A. (1984) Der Honig, Eugen Ulmer Stuttgart. 